\title{
In situ photosynthesis in the seagrass Halodule wrightii in a hypersaline subtropical lagoon*
}

\author{
Kenneth H. Dunton ${ }^{1}$, David A. Tomasko ${ }^{2}$ \\ ${ }^{1}$ Marine Science Institute, The University of Texas at Austin, Marine Science Institute, PO Box 1267, Port Aransas, \\ Texas 78373, USA \\ ${ }^{2}$ Sarasota Bay National Estuary Program, 1550 Ken Thompson Parkway, Sarasota, Florida 34236, USA
}

\begin{abstract}
Photosynthesis versus irradiance ( $P$ vs $I$ ) parameters in the shoalgrass Halodule wrightii Ascherson were calculated from measurements of oxygen evolution collected in situ, using entire plants in Laguna Madre, Texas, USA. Eleven experimental incubations were performed from May 1989 to April 1991 using pulsed oxygen electrodes that collected data continuously under natural daylight conditions. For comparison with in situ measurements of photosynthesis, $P$ vs $I$ parameters were calculated from laboratory measurements on blade segments incubated in a small volume chamber. For field plants, average saturation irradiance $\left(I_{k}\right)$ was $319 \mu \mathrm{mol} \mathrm{m} \mathrm{m}^{-2} \mathrm{~s}^{-1}$, photosynthetic capacity $\left(P_{\max }\right)$ was $374 \mu \mathrm{mol} \mathrm{O}_{2} \mathrm{~g}^{-1}$ dry wt $(\mathrm{dw}) \mathrm{h}^{-1}$, and relative quantum efficiency $(\alpha)$ generally ranged from 0.5 to $1.6 \mu \mathrm{mol} \mathrm{O} \mathrm{g}^{-1} \mathrm{dw} \mathrm{h}^{-1}\left(\mu \mathrm{mol} \text { photons } \mathrm{m}^{-2} \mathrm{~s}^{-1}\right)^{-1}$. Whole plant respiration was $70 \mu \mathrm{mol} \mathrm{g}^{-1} \mathrm{dw}$ (leaf) $\mathrm{h}^{-1}$,

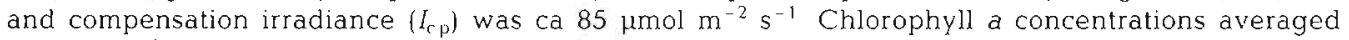
$12.8 \mathrm{mg} \mathrm{g}^{-1} \mathrm{dw}$, and the mean chl $a$ :chl $b$ ratio over the $2 \mathrm{yr}$ period was 2.2 . For blade segments incubated in the laboratory under similar temperatures to field plants and at corresponding chlorophyll concentrations, $P_{\operatorname{mux}}$ was not significantly different but $\alpha$ was significantly higher, ranging from 3.4 to $5.3 \mu \mathrm{mol} \mathrm{O} \mathrm{g}^{-1} \mathrm{dw} \mathrm{h}^{-1}$ ( $\mu \mathrm{mol}$ photons $\left.\mathrm{m}^{-2} \mathrm{~s}^{-1}\right)^{-1}$ The higher $\alpha$ values resulted in significantly lower estimates for $I_{k}$ (mean of $101 \mu \mathrm{mol} \mathrm{m} \mathrm{m}^{-2} \mathrm{~s}^{-1}$ ). The higher $\alpha$ in laboratory plants was largely related to the perpendicular orientation of leaf tissue to a directed light field, which is not reflective of natural conditions for $H$. wrightii. The significant difference in $I_{k}$ values calculated from incubations performed in the laboratory and field has profound effects on model calculations of $H_{\text {sal }}$ the duration of irradiancesaturated photosynthesis, and thus predictions of the minimum light requirements required to sustain growth in $H$. wrightii. Consequently, the application of laboratory-derived $I_{k}$ values for $H$. wrightii would result in overestimates of its maximum depth limits and rates of areal primary production.
\end{abstract}

KEY WORDS: Photosynthesis - Seagrasses · Halodule wrightii - Texas - Subtropical · Light - PAR Photophysiology $\cdot$ Shoalgrass

\section{INTRODUCTION}

There are no cornfields in the sea, yet seagrass meadows occur over vast areas and are among the most productive of plant communities (McRoy \& McMillan 1977). They provide important structural complexity to coastal habitats and are used both as substrata and food for a wide variety of flora and fauna, including endangered sea turtles (Thayer et al. 1975, Fry \& Parker 1979, Bjorndall 1980, McRoy \& Helfferich 1980).

- The University of Texas at Austin, Marine Science Institute Contribution No. 900
In Texas, USA, the occurrence of high finfish production in estuaries dominated by seagrasses and the concentration of overwintering waterfowl in seagrass meadows are no coincidence. In Laguna Madre, which produces more than $66 \%$ of the state's annual finfish harvest (Hedgpeth 1967), Hellier (1962) and Odum \& Wilson (1962) found a positive correlation between gross photosynthesis ( $95 \%$ of which is seagrass or algal epiphytes) and fish biomass. In addition, Cornelius (1977) found that 4 to $5 \%$ of the autumn standing crop of the shoalgrass Halodule wrightii in Laguna Madre was consumed by redhead ducks. McMahan (1969) calculated that shoalgrass made up 84 to $89 \%$ of the diet for pintail and redhead ducks. 
Despite the large volume of information published on the trophic and functional value of seagrasses, our knowledge of the basic biology of this group is still inadequate to sufficiently predict the effects of environmental perturbations on seagrass growth and productivity (Zimmerman et al. 1991). For example, Laguna Madre is characterized by over $730 \mathrm{~km}^{2}$ of seagrass meadows composed of 5 different species (Quammen \& Onuf 1993) that represent about 85\% of total seagrass vegetation in the entire coastal zone of Texas (Onuf pers. comm.). Yet losses of seagrasses in the lower Laguna Madre since the mid-1970s have been documented by McMahan (1969) and Merkord (1978). A vegetational survey in 1988 by Quammen \& Onuf (1993) confirmed a $140 \mathrm{~km}^{2}$ decrease in cover since 1965-67. The decline in seagrass cover has been attributed to light reduction caused by high turbidities that resulted from maintenance dredging (Merkord 1978, Quammen \& Onuf 1993, Onuf 1994). In addition, the occurrence of a brown tide algal bloom in Laguna Madre since June 1990 has further stressed seagrass populations through chronic light reduction (Dunton 1994).

It is clear that predicting the effect of chronic reductions in underwater irradiance, as well as efforts to manage the remaining seagrass resources through habitat restoration and the establishment of water transparency criteria, require an accurate knowledge of the plant's photosynthetic light requirements. Such quantitative information becomes extremely valuable when combined with long-term in situ measurements of photosynthetically active radiation (PAR). Few studies have addressed photosynthetic carbon production in conjunction with definitive measurements of PAR for accurate calculation of photosynthesis versus irradiance ( $P$ vs $I$ ) parameters. However, even for species which have been studied extensively, such as Zostera marina, measurements of saturation irradiance can vary considerably (e.g. from 35 to $230 \mu \mathrm{mol}$ photons $\mathrm{m}^{-2} \mathrm{~s}^{-1}$ at $15^{\circ} \mathrm{C}$; Drew 1979 , Zimmerman et al. 1989). Such variations may be a product of the techniques employed rather than a reflection of actual differences in a species' photosynthetic physiology. This further complicates the use of $P$ vs I parameters in explaining the current distribution of seagrasses from measurements of underwater light fields.

In this study, we examined the photosynthetic rates for entire Halodule wrightii plants from in situ incubations made periodically over a 2 yr period in Laguna Madre, Texas. We also made concurrent measurements of underwater quantum irradiance to estimate parameters of photosynthetic efficiency and levels of light saturation for this species. Pigment levels within the leaves were also assessed to determine if any variations in $P$ vs $I$ parameters could be related to changes in chlorophyll $a$ and $b$ (chl $a$ and $b$ ) content. For comparison to field measurements of photosynthesis, leaf segments of $H$. wrightii were also incubated under carefully controlled conditions of light and temperature in the laboratory. The 2 approaches yielded significantly different results and indicated that the use of saturation irradiance values derived from laboratory measurements of photosynthesis may not always be appropriate in the development of models to predict seagrass depth distributions and productivity in the marine environment.

\section{METHODS}

In situ photosynthetic measurements. We examined $P$ vs $I$ relationships in a monotypic meadow of Halo-

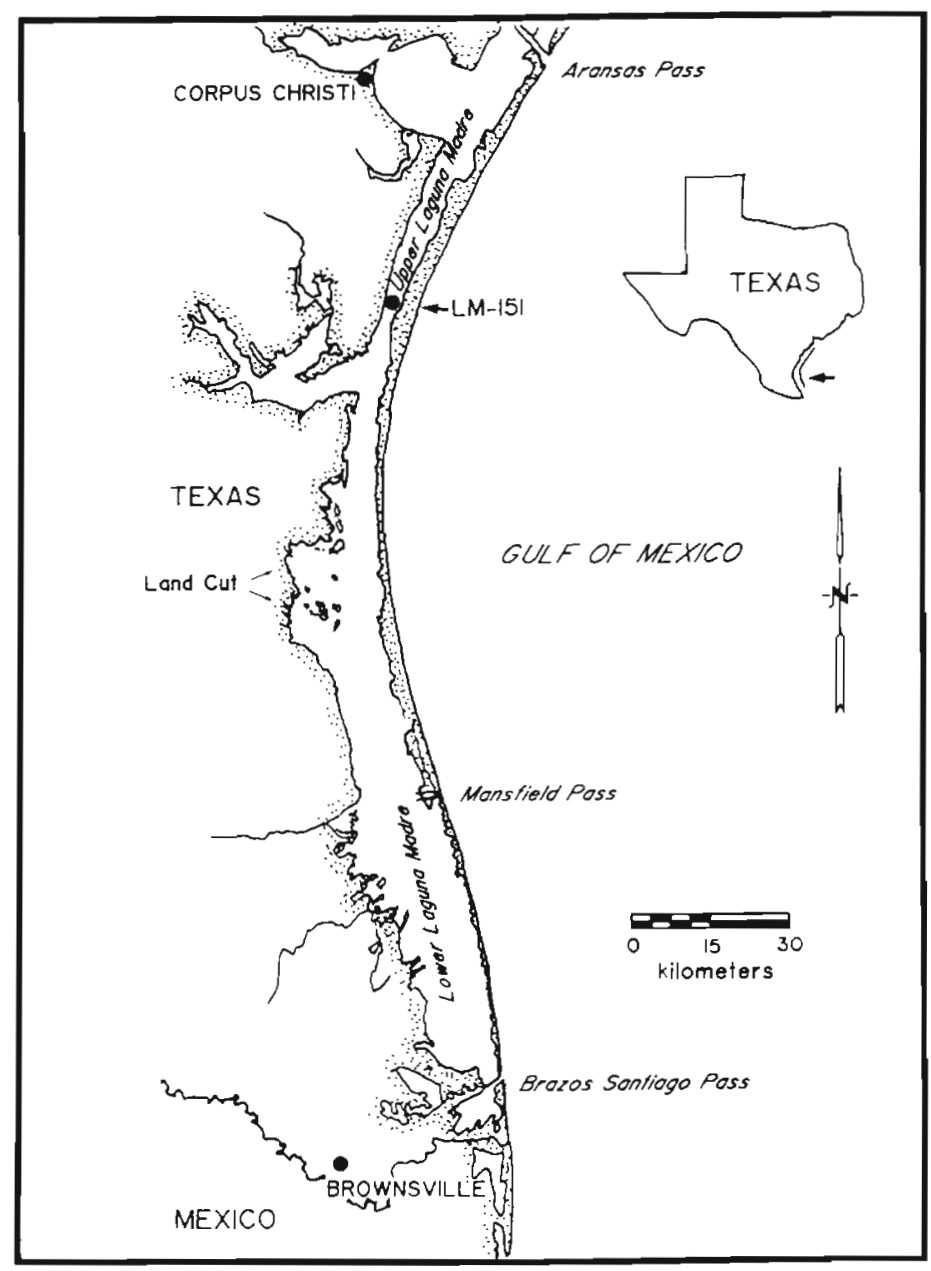

Fig. 1. Location of the experimental study site (LM-151) in the upper Laguna Madre, Texas, USA 
dule wrightii in the upper Laguna Madre, Texas (Station LM-151; $27^{\circ} 21^{\prime} \mathrm{N}_{;} 97^{\circ} 22^{\prime} \mathrm{W}$; Fig. 1). The average depth at this site was $1.3 \mathrm{~m}$ (Dunton 1994) which is close to the maximum depth penetration for actively growing populations of $H$. wrightii (1.6 to $1.8 \mathrm{~m}$; Onuf pers. comm.) in upper Laguna Madre.

Experimental incubations were conducted at 2 to 4 mo intervals from May 1989 to April 1991. About $2 \mathrm{wk}$ prior to the in situ work, we removed dead leaves, algal epiphytes and drift macroscopic algae within a $2 \mathrm{~m}^{2}$ area. Algal epiphytes were seldom observed on leaves of Halodule wrightii in Laguna Madre, and may be related to the hypersaline conditions and low nutrient concentrations in the upper Laguna (Jewett-Smith 1991). If present, epiphytes were either removed by hand or by clipping the top few centimeters of the oldest blades having the highest concentration of these attached plants. Immediately prior to the deployment of incubation chambers on the seabed, the area was again raked clean of detritus and macroalgae.

Photosynthetic incubations of whole plants were conducted in situ using four $5 \mathrm{I}$ chambers placed on the seabed by divers. Clear acrylic plastic chambers were $12 \mathrm{~cm}$ in diameter and $45 \mathrm{~cm}$ high (Fig. 2). The top of each chamber was permanently sealed and contained a tapered opening for an oxygen probe and a $1.2 \mathrm{~cm}$ diameter sampling port plugged with a rubber septum. A small battery-powered submersible pump provided circular water movement within the chamber for $3 \mathrm{~min}$ periods at 2 min intervals, as triggered by an external computer running in BASIC. During deployment of the chambers, care was taken to avoid cutting shoots or blades while they were positioned and pressed firmly into the seabed to a depth of $10 \mathrm{~cm}$. Underwater PAR $(400$ to $700 \mathrm{~nm})$ was measured at $5 \mathrm{~s}$ intervals and integrated every $5 \mathrm{~min}$ on a continuous basis using an LI193SA spherical quantum sensor, which provided input to a LI-1000 datalogger (LI-COR, Lincoln, NE, USA). The sensor was placed adjacent to the chambers at canopy level (Fig. 2). Salinity was determined in the field using a refractometer calibrated against an Orion 140 salinometer

Dissolved oxygen measurements were collected using an Endeco/YSI Type 1125 Pulsed Dissolved Oxygen System. The system utilizes 4 YSI 1128 oxygen electrodes, is flow insensitive, offers high resolution $( \pm 0.4 \mu \mathrm{M})$, and is capable of collecting continuous measurements of dissolved oxygen and temperature at selectable intervals. For incubations with Halodule wrightii, the probes were programmed to collect measurements of dissolved oxygen at $15 \mathrm{~min}$ intervals. Chambers were typically deployed by $18: 00 \mathrm{~h}$ and allowed to equilibrate for several hours prior to data collection. Once oxygen values had stabilized, water samples were collected periodically for oxygen determinations using the Winkler method (Strickland \& Parsons 1972) to insure that the probes were operating within calibration (calibrations were conducted in the laboratory prior to the cruise). Constant monitoring of the data output via RS-232 interface to a laptop computer using Endeco software permitted the monitoring of oxygen tensions within the chambers and avoidance of saturating oxygen concentrations. If saturation occurred, oxygen levels were reduced 40 to $50 \%$ by bubbling $\mathrm{N}_{2}$ into the chamber for 2 to $3 \mathrm{~min}$. Any
Fig. 2. Photosynthetic oxygen chamber used for in situ incubations in Laguna Madre. Four chambers constructed entirely of clear acrylic were employed simultaneously during each incubation. See text concerning details of data acquisition

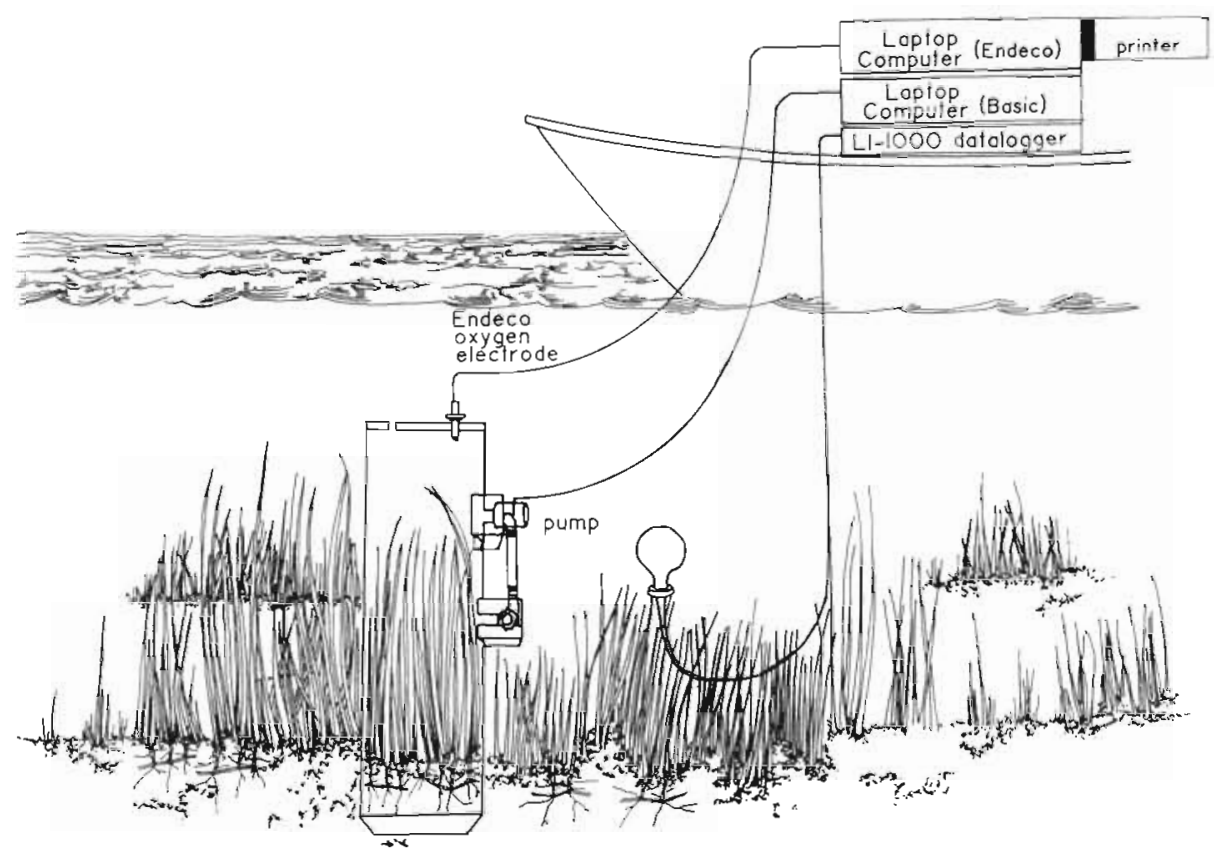


remaining gas bubbles were removed using the $1.2 \mathrm{~cm}$ diameter sampling port at the top of the chamber. Plants were incubated under natural daylight conditions, although neutral density shade cloth was occasionally deployed over the chambers to achieve a desired light level. Incubations generally ranged from 0.5 to $1.5 \mathrm{~h}$ to maintain a given light level. To assess the effect of phytoplankton on oxygen levels within the chambers, we performed light and dark bottle incubations and obtained total water column chlorophyll concentrations following Parsons et al. (1984). Although the contributions made by phytoplankton were usually insignificant $\left(<5 \%\right.$ of chamber photosynthesis at $P_{\max }$ ), the onset of a brown algal chrysophyte bloom in late spring 1990 caused significant increases in chlorophyll concentrations in the upper Laguna Madre (Stockwell et al. 1993). To avoid the necessity of making corrections for the oxygen contributions made by phytoplankton, the water within the chambers was cycled sequentially through 10 and $1 \mu \mathrm{m}$ filter cartridges for a $15 \mathrm{~min}$ period. This procedure effectively reduced chlorophyll concentrations in the chambers to negligible levels.

Photosynthetic rates were calculated from changes in dissolved oxygen concentrations in the chamber over the duration of each incubation. Net chamber photosynthesis was determined from slopes by regression analysis of linear portions of recorded time series at each light level. Chamber respiration rates (for calculation of plant, animal, bacterial and chemical oxygen demand) were determined from incubations conducted the evening prior to the photosynthetic incubation. Respiration by non-seagrass tissues was variable but generally accounted for 10 to $50 \%$ of total chamber respiration. Gross photosynthesis at each light level $\left(P_{G(I)}\right)$ among the 4 replicate chambers was calculated similarly to that outlined by Fourqurean \& Zieman (1991) in which $P_{G(l)}$ represents the sum of net chamber photosynthesis and chamber respiration, normalized to the pigmented shoot and leaf biomass in the chamber $\left(B_{\text {leaf }}\right)$ :

$$
P_{G(I)}=\frac{\left|P_{\text {chamber net }(f)}+R_{\text {chamber }}\right|}{B_{\text {leat }}}
$$

Gross photosynthetic rates were expressed in units of $\mu \mathrm{mol} \mathrm{O} \mathrm{O}^{-1}$ dry wt leaf $\mathrm{h}^{-1}$

$P$ vs $I$ model calculations. $P$ vs $I$ data were fit to the hyperbolic tangent function of Jassby \& Platt (1976):

$$
P=P_{\max } \tanh \left(\frac{\alpha I}{P_{\max }}\right)
$$

where $P_{\max }$ is the light-saturated rate of photosynthesis, $\alpha$ is light-limited slope of $P$ vs $I$ curve and $I$ is the irradiance. This function usually provides the best fit to $P$ vs $I$ curves based on both goodness of fit and mini- mizing residuals as reported for phytoplankton and marine macroalgae (Chalker 1980, Coutinho \& Zingmark 1987, Geider \& Osborne 1992). All curve-fitting was performed statistically on a 486 PC using nonlinear least squares regression techniques (SAS Institute 1987). $P$ vs $I$ parameters were estimated simultaneously using a derivative-free algorithm (The Dudly algorithm) of Ralston \& Jennrich (1978). The saturation irradiance, $I_{k}$, was defined as the ratio of the 2 model parameters, $\alpha$ and $P_{\max }$ :

$$
I_{k}=\frac{P_{\max }}{\alpha}
$$

Respiration and calculation of whole-plant compensation irradiance. Estimation of the compensation irradiance for an entire plant (blades and their associated below-ground tissues), required a knowledge of the root:shoot ratios ( $R S R$ ) for Halodule wrightii and measurements of leaf and root/rhizome dark respiration rates. During each experimental chamber incubation, we collected blade and root/rhizome material for dark bottle incubations performed at night in situ. Samples containing entire blades and root/rhizome tissue were separated and washed immediately after collection and sorted into 4 replicate $300 \mathrm{ml}$ BOD bottles for each tissue type. Two additional bottles were deployed to correct for water column respiration, which normally exhibited negligible oxygen uptake over the 2 to $3 \mathrm{~h}$ incubation period. Oxygen concentrations in each bottle were measured using an oxygen electrode or by chemical analysis using the Winkler Method (Parsons et al. 1984). The incubated shoot and root/rhizome tissue was then dried to a constant weight at $60^{\circ} \mathrm{C}$ for 24 to $48 \mathrm{~h}$. Results are expressed in $\mu \mathrm{mol} \mathrm{O} 2 \mathrm{~g}^{-1} \mathrm{dry}$ wt (dw) tissue $\mathrm{h}^{-1}$.

The apportionment of above- and below-ground tissue was measured from biomass samples retrieved from the 4 experimental chambers used in the $P$ vs $I$ incubations. Pigmented leaves and shoots (aboveground tissue) were separated from non-photosynthetic shoot and root/rhizome portions; the tissues were washed sequentially through $12 \mathrm{~mm}$ and $1.0 \mathrm{~mm}$ mesh screens to remove sediments, detritus, and shell material. The pooled material from the 2 components were dried and indices of $R S R$ determined. Total plant respiration $\left(R_{\mathrm{p}}\right)$ was normalized to $1 \mathrm{~g}$ dry wt of leaf tissue and calculated from the respiratory demands of leaf tissue $\left(R_{\text {leat }}\right)$ and root/rhizome $\left(R_{r / r}\right)$ tissue based on the proportion of root/rhizome tissue needed to support that leaf tissue (the $R S R$ ratio):

$$
R_{\mathrm{p}}=R_{\text {leal }}+R_{\mathrm{r} / \mathrm{r}}(R S R)
$$

Whole plant compensation irradiance $\left(I_{c p}\right)$, the light level at which the rate of photosynthetic oxygen evolution $(P)$ is equivalent to the total respiratory demands 
of the plant $\left(R_{\mathrm{p}}\right)$, was then determined mathematically from the hyperbolic tangent function by setting $R_{\mathrm{p}}$ equal to $P$, substituting $I_{\mathrm{cp}}$ for $I$ in Eq. (2) and solving for $I_{\mathrm{cp}}$ :

$$
I_{c p}=\left(\frac{P}{P_{\max }}\right) \operatorname{coth}\left(\frac{\alpha}{P_{\max }}\right)
$$

Laboratory $P$ vs $I$ measurements. For comparison with in situ measurements of photosynthesis, vegetative shoots were collected from cores gathered at the study site in late April 1993 for laboratory-based metabolic rate measurements. Entire plants (shoots, roots and associated sediment) were placed in holding tanks with continuous running seawater $\left(25\right.$ to $\left.26^{\circ} \mathrm{C}\right)$ and exposed to ca $100 \mu \mathrm{mol}$ photons $\mathrm{m}^{-2} \mathrm{~s}^{-1}$ under a daily photoperiod of $12 \mathrm{~h}$ light:12 h dark under fluorescent lamps. Leaf segments ( $3 \mathrm{~cm}$ lengths) were cut 2 to $4 \mathrm{~h}$ prior to the start of the physiological measurements to minimize the effects of wound respiration (blade tissue turned increasingly brown from cut areas if held $>12 \mathrm{~h}$ ). Plants were incubated within 1 to $3 \mathrm{~d}$ of initial collection. We performed the $P$ vs $I$ measurements at $29^{\circ} \mathrm{C}$ to facilitate direct comparison with field incubations. Five of the eleven in situ incubations were conducted at temperatures ranging between 28 and $30^{\circ} \mathrm{C}$ (mean $29^{\circ} \mathrm{C}$ ) and provided a sufficient sample for statistical comparison at this temperature.

Oxygenic photosynthesis and respiration rates were measured on leaf segments using a polarographic $\mathrm{O}_{2}$ electrode in a modified water-jacketed incubation chamber (13 ml vol; Rank Bros., Bottisham, UK). The electrode was calibrated using $\mathrm{N}_{2}$-purged and airsaturated media. An underwater LI-192SA quantum sensor fitted on one side of the square chamber and connected to a LI-1000 datalogger provided accurate measurement of PFD (photon flux density) within the chamber. Photosynthetic rates were measured at 10 different irradiances using a Kodak slide projector (300 W ELH G.E. bulb) as a light source and slides fabricated from Kodak neutral density filters. Respiration rates were measured in the dark. Initial $\mathrm{O}_{2}$ concentrations were decreased to about $25 \%$ of air saturation by bubbling with $\mathrm{N}_{2}$ immediately prior to photosynthetic measurements, which proceeded sequentially from the lowest $\left(6 \mu \mathrm{mol} \mathrm{m} \mathrm{m}^{-2} \mathrm{~s}^{-1}\right)$ to the highest $\left(1100 \mu \mathrm{mol} \mathrm{m} \mathrm{m}^{-2}\right.$ $\mathrm{s}^{-1}$ ) level of PAR. Rates of dark respiration were performed near levels of oxygen saturation prior to the start of the photosynthetic incubations. Temperature was controlled at $29.0 \pm 0.5^{\circ} \mathrm{C}$ by a refrigerated circulating water bath; a magnetic stirrer insured rapid mixing for both the electrode and the tissue segment. Digital data output was recorded continuously using a Computer Boards A/D converter and Labtech Notebook Software (Ver. 6.3.0) running under MS-DOS on a 286-AT computer. Slopes were determined as

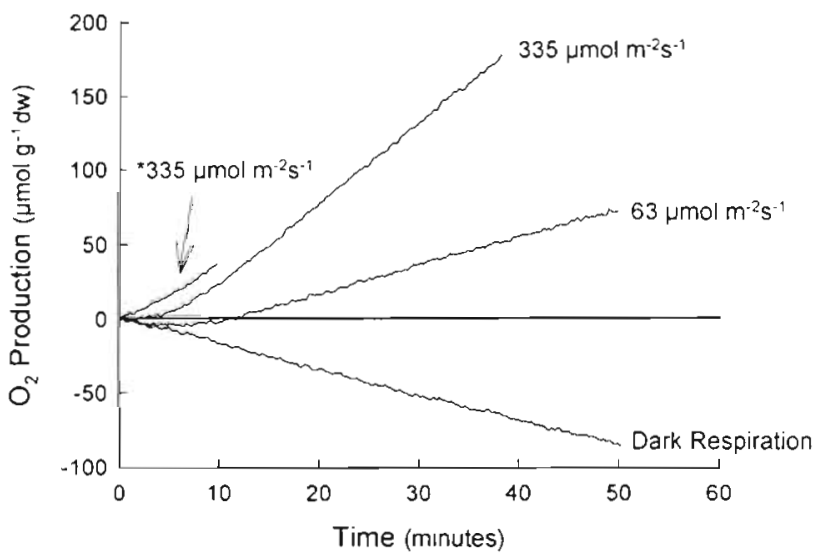

Fig. 3. Halodule wrightii. Photosynthetic oxygen evolution and respiratory uptake in blade segments as a function of time at different light levels. Asterisk denotes light level that was not preceded by a 6 min dark period (see text)

described above for incubations that averaged 4 to $6 \mathrm{~min}$. $P$ vs $I$ data were fit to the hyperbolic tangent function (Eq. 2) of Jassby \& Platt (1976); leaf compensation irradiance $\left(I_{c(\text { leaf })}\right)$ was determined similarly as denoted for $I_{\mathrm{cp}}$ in Eq. (5).

Because of concerns about effects of lacunal gas storage on the measurement of photosynthesis, we established a minimal period of stabilization following introduction of blade tissue into the chamber and after establishment of each new light level. The duration of this period was based on a time-course experiment at 3 different light levels, similar to that performed by Drew (1978). The results (Fig. 3) show that a constant rate of oxygen evolution into the incubation chamber was delayed from 1 to $10 \mathrm{~min}$ as a function of light level and prior exposure to darkness. The lag period for dark respiration was less than $3 \mathrm{~min}$, but was about $10 \mathrm{~min}$ at $63 \mu \mathrm{mol} \mathrm{m} \mathrm{m}^{-2} \mathrm{~s}^{-1}$ (following dark respiration) and

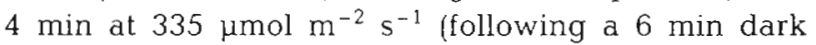
period). However, the lag period dropped to about $1 \mathrm{~min}$ at $335 \mu \mathrm{mal} \mathrm{m} \mathrm{m}^{-2} \mathrm{~s}^{-1}$ if no dark period preceded the measurement (the linear slopes remained the same). These observations became the basis for the procedure outlined above, in which blade segments were measured at sequential increases in PAR following the measurement of dark respiration with the incorporation of a 4 min stabilization period prior to each measurement.

Measurement of leaf chlorophyll content. Until October 1992, we extracted chlorophylls from leaf tissue by repeated grinding of pre-weighed tissue samples in $90 \%$ cold acetone buffered with $0.05 \% \mathrm{MgCO}_{3}$ using chilled pestles and mortars with washed sea sand. The extract was made up to a known volume, centrifuged, and absorbances measured at 664 and 
$647 \mathrm{~nm}$ on a Shimadzu UV $160 \mathrm{U}$ spectrophotometer. $C h l a$ and $b$ content was then determined using the equations from Jeffrey \& Humphrey (1975) for 90\% acetone. After October 1992, we employed an alternative extraction technique utilizing $\mathrm{N}, \mathrm{N}$-dimethyl formamide (DMF) which did not require grinding of plant tissue, thus saving time and effort as well as reducing potential sources of error. Pre-weighed tissue samples were extracted overnight in glass screw-cap tubes containing $\mathrm{DMF}$; the resulting extract was measured as described above and chl $a$ and $b$ content determined using the equations of Porra et al. (1989). Appropriate corrections were made for a turbidity blank at $750 \mathrm{~nm}$ in both methods. Comparison of the results using the 2 techniques on blade tissue collected on a variety of occasions yielded no significant differences in chl a or chl $b$ content (paired $t$-test, $\mathrm{p} \geq 0.65$ and $\mathrm{p} \geq 0.08$ respectively, $n=12$ ).

Statistics. Siatistical analyses were performed on a 486 PC using a general linear model procedure (SAS Institute Inc. 1987). Significant differences in chlorophyll content among sampling dates was tested using a 1 -way ANOVA. When a significant difference for a main effect $(p<0.05)$ was observed, the means were analyzed by a Tukey multiple-comparison test to de- termine significant differences among sampling dates. Significant differences in $P$ vs $I$ parameters were tested using a 2-sample $t$-test.

\section{RESULTS}

\section{In situ photosynthesis of entire plants}

The $P$ vs $I$ curves for Halodule wrightii plants incubated in situ over a 2 yr period in Laguna Madre exhibited marked similarity (Fig. 4). Photosynthetic relationships were explained well by the hyperbolic tangent function of Jassby \& Platt (1976), with all curves exhibiting an $\mathrm{r}^{2}>0.95$. Incubations conducted throughout the day at a variety of light levels showed, in most instances, no apparent or consistent differences in photosynthetic oxygen production between morning and afternoon periods at similar light levels. No obvious seasonal trends in $P$ vs $I$ parameters were apparent, despite temperatures that ranged from 12 to $30^{\circ} \mathrm{C}$ over the course of this study.

Excluding the high $P_{\max }$ and $I_{k}$ values obtained in January 1990, gross $P_{\max }$ averaged $374 \mu \mathrm{mol} \mathrm{O} \mathrm{g}^{-1} \mathrm{dw}$ leaf $\mathrm{h}^{-1}$, and $I_{k}$ averaged $319 \mu \mathrm{mol}$ photons $\mathrm{m}^{-2} \mathrm{~s}^{-1}$

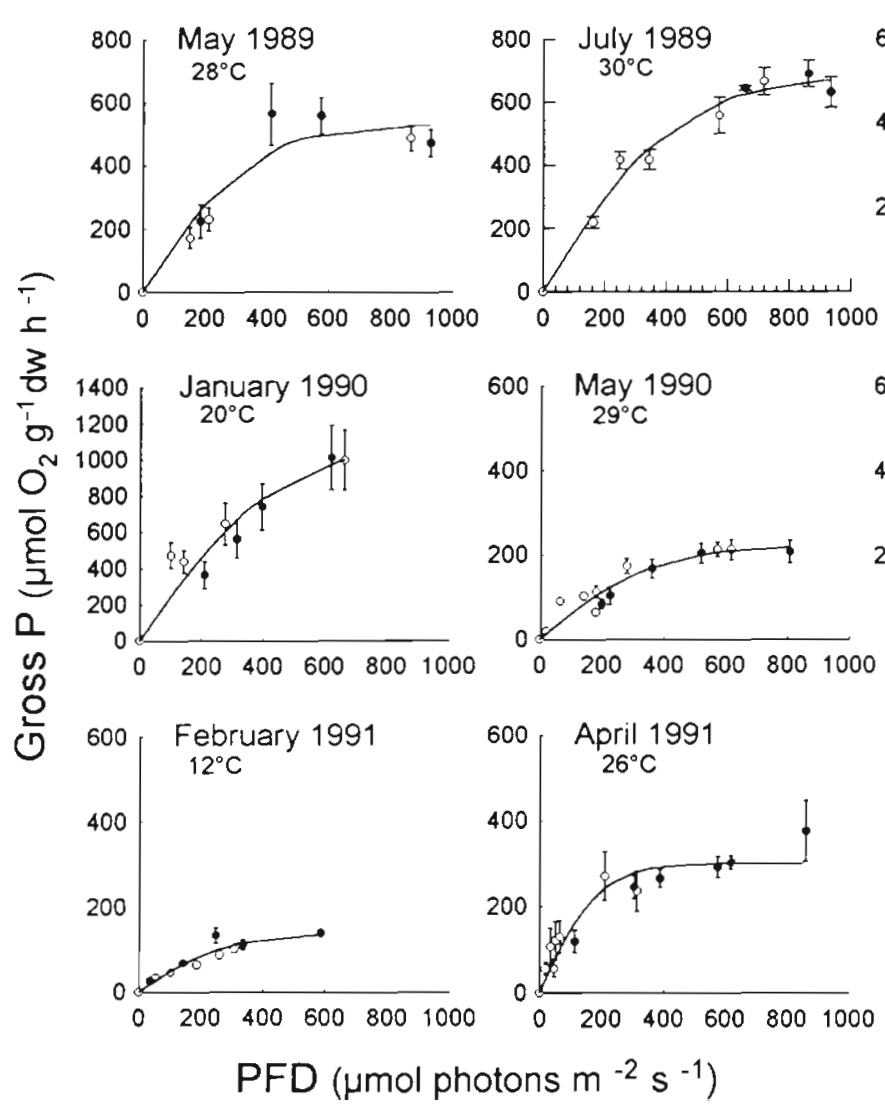

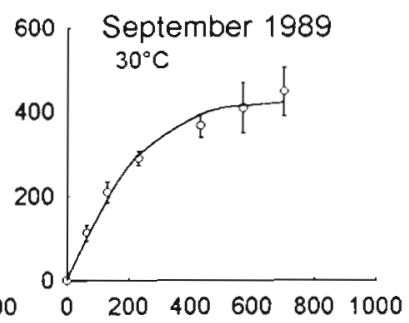
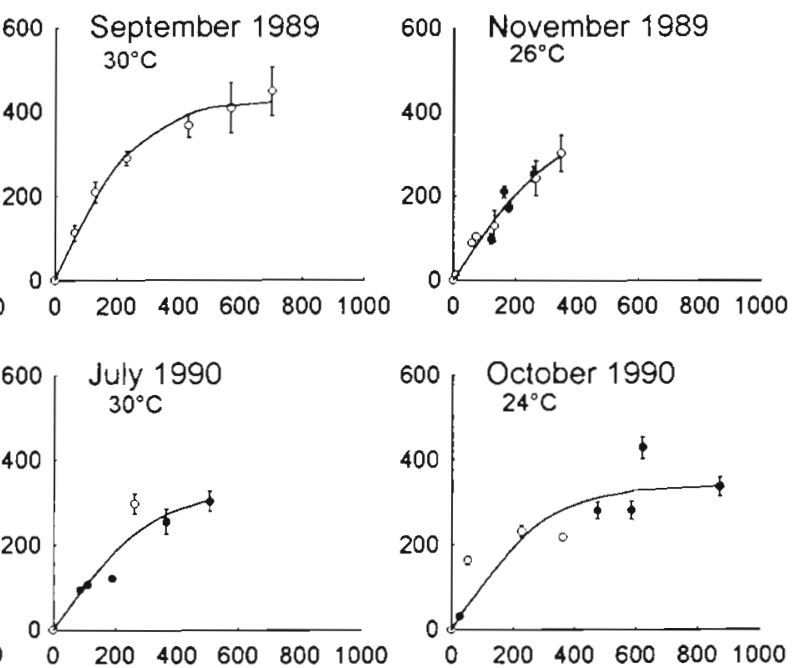

PFD ( $\mu \mathrm{mol}$ photons $\mathrm{m}^{-2} \mathrm{~s}^{-1}$ )

Fig. 4. Halodule wrightii. $P$ vs $I$ curves. Relationship between photosynthetic oxygen production and PFD measured in situ for entire plants from May 1989 to April 1991. Values are $\bar{x} \pm \mathrm{SE}_{;} \mathrm{n}=3$ to 4 for most light levels achieved in morning $(0)$ or afternoon $(\bullet)$. Where no error bars appear, $\mathrm{SE}$ is less than the size of the symbol. Note adjustment in $y$-axis scale between some months 
Table 1. Halodule wrightii. Seasonal variation in the $P$ vs $I$ parameters for entire plants based on in situ measurements of oxygen evolution and root:shoot ratios $(R S R)$

\begin{tabular}{|c|c|c|c|c|c|c|c|c|}
\hline Date & $\begin{array}{l}\text { Temp. } \\
\left({ }^{\circ} \mathrm{C}\right)\end{array}$ & $\begin{array}{c}\text { Salinity } \\
(\% 0)\end{array}$ & $\begin{array}{r}P_{\max } \\
(\mu \mathrm{mol} \mathrm{O}\end{array}$ & $\begin{array}{c}R \\
\text { w leaf } h^{-1} \text { ) }\end{array}$ & \multicolumn{4}{|c|}{$\begin{array}{l}I_{k} \\
\left(\mu \mathrm{mol} \mathrm{m}^{-2} \mathrm{~s}^{-1}\right)\end{array}$} \\
\hline May 1989 & 28 & 45 & 533 & 117 & 1.5 & 353 & 177 & 4.9 \\
\hline Jul 1989 & 30 & 47 & 688 & 75 & 1.6 & 434 & 119 & 3.0 \\
\hline Sep 1989 & 30 & 48 & 427 & 59 & 1.6 & 270 & 93 & 4.2 \\
\hline Nov 1989 & 26 & 45 & 386 & 89 & 1.1 & 345 & 100 & 2.0 \\
\hline Jan 1990 & 20 & 39 & 1104 & 58 & 2.4 & 453 & 141 & 5.4 \\
\hline Mar 1990 & 19 & 48 & - & - & 0.6 & - & 70 & 2.4 \\
\hline May 1990 & 29 & 38 & 223 & 76 & 0.6 & 365 & 46 & 1.7 \\
\hline Jul 1990 & 30 & 45 & 331 & 116 & 1.0 & 321 & 120 & 2.1 \\
\hline Oct 1990 & 24 & 50 & 340 & 72 & 1.1 & 306 & 80 & 1.4 \\
\hline Feb 1991 & 12 & 32 & 140 & 75 & 0.5 & 286 & 37 & 2.6 \\
\hline Apr 1991 & 26 & 45 & 300 & 62 & 1.6 & 189 & 98 & 1.3 \\
\hline
\end{tabular}

(Table 1). No data on these parameters are available for March 1990 since maximum PFD achieved during the entire incubation period was $343 \mu \mathrm{mol} \mathrm{m} \mathrm{m}^{-2} \mathrm{~s}^{-1}$ due to low incident PAR under a heavy overcast. The lowest $P_{\max }$ value recorded ( $140 \mu \mathrm{mol} \mathrm{O} \mathrm{O}^{-1}$ dw leaf $\mathrm{h}^{-1}$ ) occurred in February 1991 at an incubation temperature of $12^{\circ} \mathrm{C}$. This contrasts with the high $P_{\max }$ value of $1105 \mu \mathrm{mol} \mathrm{O} \mathrm{O}_{2} \mathrm{~g}^{-1} \mathrm{dw}$ leaf $\mathrm{h}^{-1}$ the previous January at $20^{\circ} \mathrm{C}$. Values of relative quantum efficiency, $\alpha$, ranged from 0.5 to $1.6 \mu \mathrm{mol} \mathrm{O} 2 \mathrm{~g}^{-1} \mathrm{dw}$ leaf $\mathrm{h}^{-1}$ ( $\mu \mathrm{mol}$ photons $\mathrm{m}^{-2} \mathrm{~s}^{-1} \mathrm{j}^{-1}$ excluding the January 1990 value of 2.4 . Whole plant respiration generally ranged from about 60 to $90 \mu \mathrm{mol} \mathrm{O} \mathrm{g} \mathrm{g}^{-1} \mathrm{dw}$ leaf $\mathrm{h}^{-1}$ (average $71 \mu \mathrm{mol} \mathrm{O}_{2}$ $\mathrm{g}^{-1} \mathrm{dw}$ leaf $\mathrm{h}^{-1}$, with 2 abnormally high respiration values (over $115 \mu \mathrm{mol} \mathrm{O}_{2} \mathrm{~g}^{-1} \mathrm{dw}$ leaf $\mathrm{h}^{-1}$ ) recorded in May 1989 and July 1990 (overall average of $80 \mu \mathrm{mol} \mathrm{O} \mathrm{g}^{-1}$ $\mathrm{dw}$ leaf $\mathrm{h}^{-1}$ ). Average blade respiration from bottle incubations made during each visit to the study site was $41.5(\mathrm{SE}=7.3, \mathrm{n}=11)$ compared to $16.1 \mu \mathrm{mol} \mathrm{O} \mathrm{O}_{2}$ $\mathrm{g}^{-1} \mathrm{dw} \mathrm{h}^{-1}$ (SE $\left.=4.9, \mathrm{n}=11\right)$ for root and rhizome tissue. Whole plant compensation irradiance $\left(I_{\mathrm{Cp}}\right)$ averaged $85 \mu \mathrm{mol} \mathrm{m} \mathrm{m}^{-2} \mathrm{~s}^{-1}$ for root-shoot ratios that ranged from 1.3 to 4.2 , but was much higher for ratios of about 5 or greater. Water salinities varied in response to precipitation and showed little seasonality, ranging from 32 to $52 \%$.

\section{Pigment content}

Total chlorophyll from Halodule wrightii leaf tissue ranged from 7.6 to $19.5 \mathrm{mg} \mathrm{g}^{-1} \mathrm{dw}$, with peaks at 19.5 and $19.1 \mathrm{mg} \mathrm{g}^{-1} \mathrm{dw}$ in January 1990 and May 1991 respectively (Fig. 5). Ratios of chl $a$ :chl $b$ ranged from 1.3 to 2.9 over the 2 yr period of in situ incubations with lower chl $a$ :chl $b$ ratios ( 1.3 and 2.0 respectively) corre- sponding to peaks in total chlorophyll content. The high chlorophyll concentrations and lower chl $a: \operatorname{chl} b$ ratios in $H$. wrightii coincided with the highest $P_{\max }$ (January 1990) and lowest $I_{k}$ (April 1991) recorded over the 2 yr experimental period. Blades collected in April 1993 for laboratory $P$ vs $I$ experiments exhibited a total chlorophyll concentration of $10.8 \mathrm{mg} \mathrm{g}^{-1} \mathrm{dw}(\mathrm{SE}=0.6$,
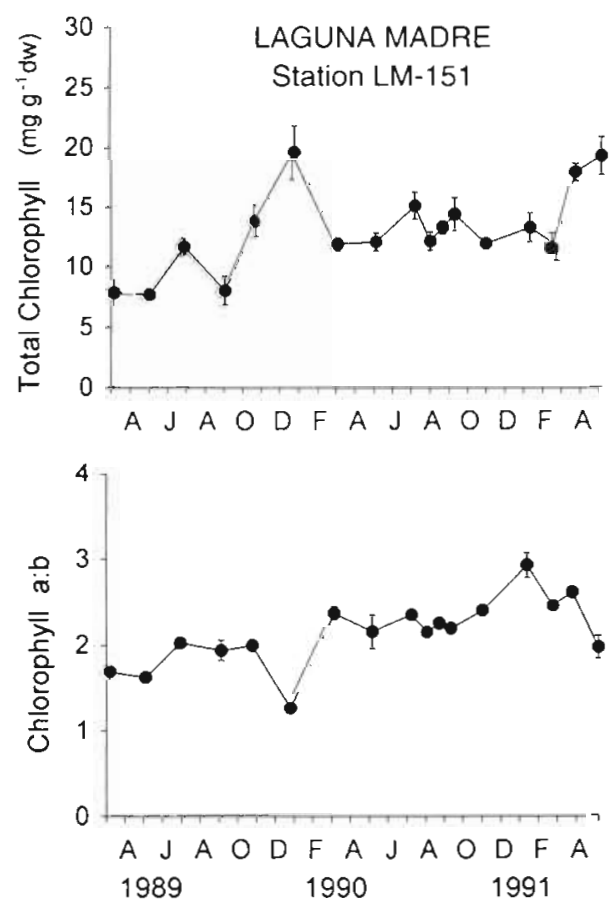

Fig. 5. Halodule wrightii. Variations in chl a content (upper panel) and chl a:chl $b$ ratios (lower panel) for plants collected from March 1989 through May 1991 at Station LM-151. Values are $\bar{x} \pm \operatorname{SE}(n=6)$. Where no error bars appear, $S E$ is less than the size of the symbol 


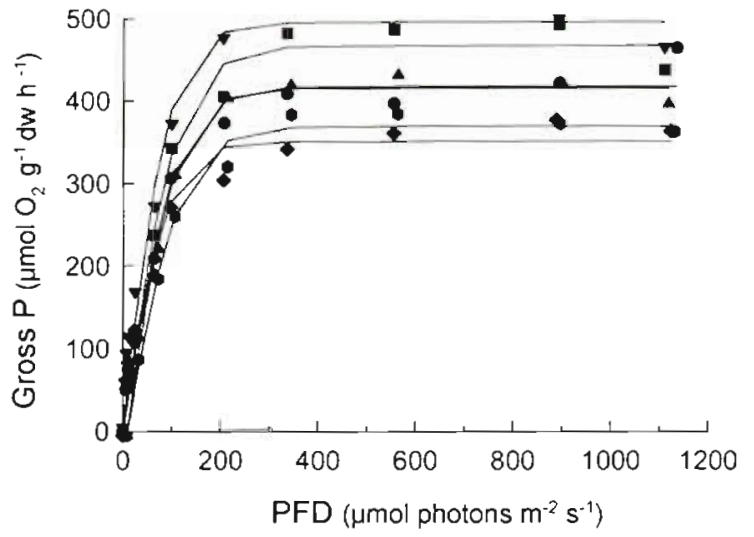

Fig. 6. Halodule wrightii. P vs $I$ curves for 6 replicate blade segments (denoted by different symbols) measured under laboratory conditions at $29^{\circ} \mathrm{C}$. Plants were collected in late April 1993 from Station LM-151

$\mathrm{n}=6$ ) and a chl $a$ :chl $b$ ratio of 2.6 , which were not significantly different ( $p>0.05$ ) from measurements collected during the 2 yr experimental period.

\section{Laboratory measurements of photosynthesis using blade segments}

Six $P$ vs $I$ curves were generated from individual blade segments of Halodule wrightii plants collected from Station LM-151 in late April 1991 (Fig. 6). Photosynthetic measurements made at $29^{\circ} \mathrm{C}$ in the laboratory were described well by the hyperbolic tangent function of Jassby \& Platt (1976), and $r^{2}$ was $>0.95$ for each of the curves.

A summary of the calculated $P$ vs $l$ parameters is shown in Table 2 . Gross $P_{\max }$ values ranged from 356 to $491 \mu \mathrm{mol} \mathrm{O} \mathrm{g}^{-1} \mathrm{dw}$ leaf $\mathrm{h}^{-1}$, similar to the range in $P_{\max }$ values derived from entire plants in situ (Table 1). However, $I_{k}$ values ranged from 90 to $110 \mu \mathrm{mol} \mathrm{m} \mathrm{m}^{-2} \mathrm{~s}^{-1}$, ca one-third the average of in situ incubated plants. Similarly, values of $\alpha$ averaged ca 3 times greater for blade segments [range 3.4 to $5.3 \mu \mathrm{mol} \mathrm{O} \mathrm{g}^{-1} \mathrm{dw}$ leaf $\mathrm{h}^{-1}$ (umol photons $\left.\mathrm{m}^{-2} \mathrm{~s}^{-1}\right)^{-1}$ ) than in whole plants incubated in situ (range 0.5 to 2.4). Since $I_{k}$ is empirically derived from estimates of $P_{\max }$ and $\alpha$, and $P_{\max }$ values were relatively the same between the 2 experimental approaches, the lower $I_{k}$ values for blade segments can be ascribed to the 3 -fold increase in $\alpha$. The higher values of $\alpha$ for blade segments is not related to total leaf chlorophyll concentrations and chl a:chl $b$ ratios, which were nearly the same as recorded from leaf tissue of entire plants incubated in situ. Statistical comparisons of the $P$ vs $I$ parameters obtained between plants incubated in the field and of blade segments measured under laboratory conditions yielded values of $I_{k}, I_{c(\text { leaf })} / I_{c p}$ and $\alpha$ that were significantly different $(p<0.05)$ between the 2 approaches.

\section{DISCUSSION}

\section{Photosynthetic light requirements of seagrasses: comparison of techniques}

Efforts to gain a more thorough and accurate understanding of the minimum light requirements necessary to sustain growth in seagrasses has focused on plant carbon budgets and the energy demands of belowground plant tissues (Zimmerman et al. 1989, Fourqurean \& Zieman 1991, Olesen \& Sand-Jensen 1993). The importance of below-ground tissues in estimating light compensation points $\left(I_{c}\right)$ was demonstrated by Olesen \& Sand-Jensen (1993), who found the $I_{c}$ for growth of entire eelgrass Zostera marina plants at $21^{\circ} \mathrm{C}$ was considerably higher $\left(47 \mu \mathrm{mol} \mathrm{m} \mathrm{m}^{-2}\right.$ $\left.\mathrm{s}^{-1}\right)$ than compared to leaves alone $\left(30 \mu \mathrm{mol} \mathrm{m} \mathrm{m}^{-2} \mathrm{~s}^{-1}\right)$. Estimates of leaf $I_{c}$ for eelgrass have been reported even lower (from 10 to $17 \mu \mathrm{mol} \mathrm{m} \mathrm{m}^{-2} \mathrm{~s}^{-1}$ ) at similar temperatures (Dennison \& Alberte 1982, Marsh et al. 1986).

The incorporation of below-ground biomass, which often accounts for up to $85 \%$ of the biomass of many seagrasses (Eleuterius 1987, Lindeboom \& Sandee 1989, Dunton 1990, Fourqurean \& Zieman 1991), can therefore have a profound impact on estimates of $I_{c}$ for entire plants, and hence on $H_{\text {comp }}$, the duration of time

Table 2. Halodule wrightii. Comparison of average $P$ vs $I$ parameters gathered from entire plants incubated in the field at 28 to $30^{\circ} \mathrm{C}$ (see Table 1) versus blade segments examined under controlled laboratory conditions at $29^{\circ} \mathrm{C}$. Values are $\bar{x} \pm \mathrm{SE}$

\begin{tabular}{|c|c|c|c|}
\hline Parameter & $\begin{array}{l}\text { Entire plants (field) } \\
\qquad(\mathrm{n}=5)\end{array}$ & $\begin{array}{l}\text { Blade segments (lab) } \\
\qquad(\mathrm{n}=6)\end{array}$ & $\begin{array}{c}\text { Comparison of } P \text { vs } I \\
\text { parameters }\end{array}$ \\
\hline $\begin{array}{l}P_{\max }\left(\mu \mathrm{mol} \mathrm{O}_{2} \mathrm{~g}^{-1} \mathrm{dw} \text { leaf } \mathrm{h}^{-1}\right) \\
\alpha\left[\mu \mathrm{mol} \mathrm{O} \mathrm{O}_{2} \mathrm{~g}^{-1} \mathrm{dw} \mathrm{h}^{-1}\left(\mu \mathrm{mol} \text { photons } \mathrm{m}^{-2} \mathrm{~s}^{-1}\right)^{-1}\right] \\
I_{K}\left(\mu \mathrm{mol} \mathrm{m} \mathrm{m}^{-2} \mathrm{~s}^{-1}\right) \\
I_{\mathrm{c}}\left(\mu \mathrm{mol} \mathrm{m} \mathrm{m}^{-2} \mathrm{~s}^{-1}\right)\end{array}$ & $\begin{aligned} 441 & \pm 80 \\
1.3 & \pm 0.2 \\
349 & \pm 27 \\
111 & \pm 21\end{aligned}$ & $\begin{aligned} 421 & \pm 21 \\
4.2 & \pm 0.3 \\
101 & \pm 4 \\
22 & \pm 2\end{aligned}$ & $\begin{array}{l}p=0.82 \\
p=0.0004 \\
p=0.0008 \\
p=0.0001\end{array}$ \\
\hline
\end{tabular}


Table 3. Variation in $I_{k}$ and $I_{c}$ values as a function of the experimental approach employed for measurement of photosynthesis in eelgrass Zostera marina. nd: not determined

\begin{tabular}{|c|c|c|c|c|c|}
\hline \multicolumn{2}{|c|}{$\begin{array}{c}I_{k} \\
\left(\mu \mathrm{mol} \mathrm{m}^{-2} \mathrm{~s}^{-1}\right)\end{array}$} & $\begin{array}{l}\text { Temp. } \\
\left({ }^{\circ} \mathrm{C}\right)\end{array}$ & Technique & $\begin{array}{l}\text { Location } \\
\text { (USA) }\end{array}$ & Source \\
\hline 230 & 28 & 15 & $\begin{array}{l}\text { Bottles, } 7 \mathrm{~cm} \text { leaf segments, } \\
\text { Winkler }\end{array}$ & California & Drew (1979) \\
\hline 100 & 10 & 20 & $\begin{array}{l}\text { Rank Bros. } \mathrm{O}_{2} \text { electrode } \\
\text { chamber, } 2 \mathrm{~cm} \text { blade segments }\end{array}$ & Woods Hole, MA & Dennison \& Alberte (1982) \\
\hline 348 & nd & 20 & $\begin{array}{l}\text { Large chambers in situ, entire } \\
\text { plants, }{ }^{14} \mathrm{C} \text { uptake }\end{array}$ & Chesapeake Bay, VA & Wetzel \& Penhale (1983) \\
\hline $65-120$ & $15-25$ & 20 & $\begin{array}{l}\text { Rank Bros. } \mathrm{O}_{2} \text { electrode } \\
\text { chamber, } 2 \mathrm{~cm} \text { blade segments }\end{array}$ & Woods Hole, MA & Dennison \& Alberte (1985) \\
\hline 78 & 17 & 20 & $\begin{array}{l}\text { Rank Bros. } \mathrm{O}_{2} \text { electrode } \\
\text { chamber, } 2 \mathrm{~cm} \text { blade segments }\end{array}$ & Woods Hole, MA & Marsh et al. (1986) \\
\hline 35 & nd & 15 & $\begin{array}{l}\text { Small-volume chamber, blade } \\
\text { segments, } \mathrm{O}_{2} \text { electrode }\end{array}$ & San Francisco Bay, CA & Zimmerman et al. (1991) \\
\hline
\end{tabular}

that PAR is above compensation irradiance. In this study, our estimates of whole plant compensation irradiance $\left(I_{\mathrm{c}}\right)$ for Halodule wrightii were also considerably higher than that of blade $I_{C}$ (Table 2). However, the reasons for this difference cannot be attributed solely to the inclusion of below-ground tissue respiration in the calculation of $I_{c p}$, since blade respiration of laboratory incubated plant segments was often greater than the respiration values calculated for entire plants measured in situ. The higher respiration for $3 \mathrm{~cm}$ blade segments may be due to a cumulative wounding effect that is minimized when using entire leaves in $300 \mathrm{ml}$ BOD bottles. However, the effect of elevated leaf segment respiration on $I_{c p}$ is minimized by the higher photosynthetic resporase of leaf tissue in laboratory incubations. The greater photosynthetic response of blade segments at limiting light levels cannot be attributed to changes in leaf chlorophyll content, which have remained virtually unchanged between 1989 and 1993 (present paper and Dunton unpubl. data). The photosynthetic performance of blade segments of $H$. wrightii from other sites in south Texas at $30^{\circ} \mathrm{C}$ have also been nearly identical to the response depicted in Fig. 6 for this species (Czerny 1994).

The measurement of photosynthesis in the laboratory, in which a small blade segment of Halodule wrightii was positioned perpendicular to a directed light field, resulted in high relative quantum efficiencies $(\alpha)$. Plants incubated in situ under a naturally diffuse underwater light field exhibited lower values of $\alpha$. In the absence of any significant difference in chlorophyll concentration, field- and laboratory-incubated plants exhibited similar rates of light-saturated photosynthesis (Table 2). Consequently, $I_{c}$ and $I_{k}$ values for laboratory-incubated plants are significantly lower.
Values of $<3 \mu \mathrm{mol} \mathrm{m}^{-2} \mathrm{~s}^{-1}$ for $I_{c}$ at temperatures of $10^{\circ} \mathrm{C}$ or less have been reported for eelgrass (Marsh et al. 1986), whose lower depth boundary corresponds to $11 \%$ of surface irradiance (Dennison 1987, Olesen \& Sand-Jensen 1993). However, $I_{c}$ values for growth in some common macroalgae are also close to this range (0.3 to $2.5 \mu \mathrm{mol} \mathrm{m} \mathrm{m}^{-2} \mathrm{~s}^{-1}$ ), yet their minimum light requirements are nearly an order of magnitude lower, 0.12 to $0.61 \%$ of surface PAR (Markager \& SandJensen 1992). Similarly, values of $35 \mu \mathrm{mol} \mathrm{m} \mathrm{m}^{-2} \mathrm{~s}^{-1}$ for saturation irradiance (at 10 to $15^{\circ} \mathrm{C}$ ) for eelgrass (Marsh et al. 1986, Zimmerman et al. 1991) are lower than reported for arctic kelp (Dunton \& Jodwalis 1988), whose total annual quantum dose of irradiance is probably received by most seagrass communities within a 1 wk summer period (Dunton 1994).

The apparent differences in the minimum light requirements needed to sustain growth and achieve light-saturated photosynthesis are largely explained by the experimental techniques employed, as shown in this study and as summarized in Table 3 for Zostera marina. In eelgrass, $I_{c}$ and $I_{k}$ values were generally lowest when blade segments were oriented perpendicular to a directed light field, usually within a small stirred chamber (e.g. Marsh et al. 1986, Zimmerman et al. 1991). In contrast, $I_{c}$ and $I_{k}$ values were considerably higher when whole leaves or blade segments were incubated in bottles or large chambers which were not purposely aligned to incoming PAR (Drew 1979, Wetzel \& Penhale 1983), as also shown in this study. Estimations of $H_{\text {sat }}$, the duration of irradiance-saturated photosynthesis (Dennison \& Alberte 1982), may therefore vary widely. The use of laboratory-derived $P$ vs $I$ parameters may lead to an overestimation of photosynthesis as argued by Fourqurean \& Zieman (1991), or to prediction of maximum depth 
limits that are not observed in the field (Zimmerman et al. 1991).

Continuous measurements of underwater irradiance near the maximum depth limits of Halodule wrightil clearly indicate that the depth limits and productivity of $H$. wrightii cannot be explained using $P$ vs $I$ parameters derived from our laboratory experiments using blade segments (Dunton 1994). Evidence for this conclusion is based on observations from 3 different estuarine systems in south Texas. Compilation of data presented in this paper and $P$ vs I measurements collected at 2 other locations in Texas (Dunton unpubl. data), have established $I_{k(f \mathrm{feld})}$ and $I_{\mathrm{cp}}$ values for $H$. wrightii of 315 and $80 \mu \mathrm{mol} \mathrm{m} \mathrm{m}^{-2} \mathrm{~s}^{-1}$ respectively. Based on this information, Dunton (1994) found that the onset of a brown algal bloom in late spring 1990 in Laguna Madre (Stockwell et al. 1993) dropped $H_{\text {sat }\{f(1 \in \mid d)}$ values from 5 to about $2 \mathrm{~h}$. The decline in $H_{\text {sat }}$ also coincided with a 24 to $46 \%$ decrease in spring leaf elongation rates and a steady decline in total plant biomass to less than half pre-brown tide levels; in contrast $H_{\text {sar (lab) val- }}$ ues exhibited little change (remaining at or above $6 \mathrm{~h}$ ) when derived from laboratory $P$ vs $I$ parameters $\left(I_{k(\mathrm{lab})}=101 \mu \mathrm{mol} \mathrm{m} \mathrm{m}^{-2} \mathrm{~s}^{-1}\right)$. At the deep edge of a seagrass bed in Corpus Christi Bay, $H_{\text {sat(1twld })}$ during spring and summer generally averaged 3 to 5 h compared to

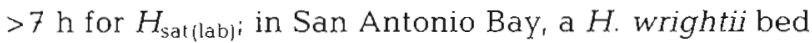
disappeared when $H_{\text {sat (field) }}$ dropped to $<2 \mathrm{~h}$ over an 8 mo period but $H_{\text {sat(lab) }}$ values remained well above $5 \mathrm{~h}$ (Dunton 1994). In all 3 examples noted above, $H_{\text {sar (lab! }}$ values were either largely insensitive to declines in water transparency to which $H$. wrightii responded, or provided unrealistic estimates of $H_{\text {sat }}$ for populations living near their maximum depth. In conclusion, although laboratory measurements of photosynthesis using blade segments are invaluable in addressing specific physiological questions [e.g. temperature effects on photosynthesis (Marsh et al. 1986), inorganic carbon uptake effects on photosynthesis (Durako 1993)] extrapolation of laboratory $P$ vs $I$ parameters to field populations may not provide the accuracy required to successfully model seagrass production from in situ measurements of PAR.

\section{Photosynthetic performance in Halodule wrightii}

We observed little variation in $P$ vs $I$ parameters in Halodule wrightii over the 2 yr experimental period. This is most likely a consequence of the small temperature range of most incubations (between 24 and $30^{\circ} \mathrm{C}$ ), the lower resolution of this approach in the measurement of photosynthetic oxygen evolution and the corrections required for chamber oxygen demand (compared to controlled laboratory experiments). In one instance we conducted $P$ vs $I$ measurements at $12^{\circ} \mathrm{C}$ (early February 1991), and found that $P_{\max }$ values dropped to $140 \mu \mathrm{mol} \mathrm{O} \mathrm{g}^{-1} \mathrm{dw}$ leaf $\mathrm{h}^{-1}$, compared to the overall average of $374 \mu \mathrm{mol} \mathrm{O} \mathrm{g}^{-1} \mathrm{dw}$ leaf $h^{-1}$ The large decrease in light-saturated photosynthesis in $H$. wrightii at $12^{\circ} \mathrm{C}$ is a consequence of reduced metabolic activity caused by the temperature dependence of the dark reactions of photosynthesis, as reported in several studies on seagrasses (reviewed by Bulthuis 1987).

In contrast, the extremely high $P_{\max }$ measured at $20^{\circ} \mathrm{C}$ in January $1990\left(1104 \mu \mathrm{mol} \mathrm{O} \mathrm{O}_{2} \mathrm{~g}^{-1} \mathrm{dw}\right.$ leaf $\left.\mathrm{h}^{-1}\right)$ corresponded with a peak in total leaf chlorophyll and low chl $a$ :chl $b$ ratios. The significant increase in blade chlorophyll followed a precipitous drop in underwater PAR during the preceding months (Dunton 1994). A second peak in blade chlorophyll content in May 1991 was also associated with extremely Iow values of underwater irradiance (Dunton 1994) and a lower $I_{k}$ valuc. Increases in chlorophyll content in aquatic plants has been associated with significant correlations in both $\alpha$ (Goldsborough \& Kemp 1988) and $P_{\max }$ (Nielsen \& Sand-Jensen 1989). These observations indicate that Halodule wrightii may possess some capacity for photosynthetic adjustment in response to its underwater light environment as reflected by changes in $P$ vs $I$ parameters. Such adjustments have been well documented in experimental manipulations with underwater irradiance for Zostera marina (Dennison \& Alberte 1985). Additionally, seagrasses from deep edges of meadows typically have higher chlorophyll content than plants from shallow edges (Drew 1978, Wiginton \& McMillan 1979, Dennison \& Alberte 1982, 1985, Dawes \& Tomasko 1988).

We observed no differences in photosynthetic production between morning and afternoon incubations at similar light levels. However, Halodule wrightii was not normally exposed to levels of PAR above $800 \mu \mathrm{mol}$ $\mathrm{m}^{-2} \mathrm{~s}^{-1}$ and failed to show any clear signs of photoinhibition at higher light levels. In contrast, Libes (1986) noted a depression in afternoon photosynthesis in Posidonia oceanica that were incubated in situ, but attributed this response to the high light conditions that occurred during the day when plants were frequently exposed to an irradiance equivalent to $1400 \mu \mathrm{mol} \mathrm{m} \mathrm{m}^{-2} \mathrm{~s}^{-1}$.

The light-saturated rates of photosynthesis for Halodule wrightii reported here are in the range of values reported for Halodule spp. in previous studies using bottles or large incubation vessels in situ (Williams \& McRoy 1982, Morgan \& Kitting 1984, Lindeboom \& Sandee 1989, Zieman et al. 1989) or under artificial light (Beer \& Waisel 1982). For H. wrightii, Williams \& McRoy (1982) noted that $P_{\max }$ ranged from about 250 to $340 \mu \mathrm{mol} \mathrm{C} \mathrm{g}^{-1} \mathrm{dw}$ leaf $\mathrm{h}^{-1}$ for Texas plants, and from about 250 to $1580 \mu \mathrm{mol} \mathrm{C} \mathrm{g}{ }^{-1} \mathrm{dw}$ leaf $\mathrm{h}^{-1}$ for Puerto 
Table 4. Comparison of light-saturated rates of gross photosynthesis among seagrasses, freshwater angiosperms, and terrestrial plants based on rates of oxygen evolution. Asterisks denote rates of carbon production that were converted to oxygen based on a photosynthetic quotient of unity

\begin{tabular}{|c|c|c|c|c|c|}
\hline Species & $\begin{array}{c}\text { Temp. } \\
\left({ }^{\circ} \mathrm{C}\right)\end{array}$ & \multicolumn{3}{|c|}{$P_{\max }, \mu \mathrm{mol} \mathrm{O} \mathrm{O}_{2} \mathrm{~h}^{-1}$} & Source \\
\hline \multicolumn{6}{|l|}{ Seagrasses } \\
\hline Cymodocea nodosa & 25 & - & 2.0 & 65.0 & Drew $(1979)$ \\
\hline Halodule wrightii & 29 & 441 & - & 34.5 & This study \\
\hline Halophila stipulacea & 25 & - & 0.8 & 62.5 & Drew (1979) \\
\hline Phyllospadix torreyi & 15 & - & 2.5 & 48.3 & Drew (1979) \\
\hline Posidona oceanica & 17 & - & 0.8 & 23.3 & Drew $(1979)$ \\
\hline Ruppia drepanensis & 16 & $67^{\circ}$ & - & $54.6^{\circ}$ & Garcia et al. (1991) \\
\hline Thalassia testidinum & 30 & 239 & - & 67.5 & Dawes \& Tomasko (1988) \\
\hline Zostera marina & 15 & - & 1.3 & 26.7 & Drew $(1979)$ \\
\hline Zostera marina & 20 & 91.2 & 0.5 & 28.2 & Dennison \& Alberte (1982) \\
\hline \multicolumn{6}{|l|}{ Freshwater angiosperms } \\
\hline Elodea canadensis & 15 & 161 & 0.1 & 19.4 & Nielsen \& Sand-Jensen (1989) \\
\hline Myriophyllum spicatum & 15 & 285 & 0.1 & 28.1 & Nielsen \& Sand-Jensen (1989) \\
\hline Potamogeton crispus & 15 & 562 & 0.2 & 32.8 & Nielsen \& Sand-Jensen (1989) \\
\hline \multicolumn{6}{|l|}{ Terrestrial plants } \\
\hline Shade plants & 25 & - & $0.8^{*}$ & $9.2^{\circ}$ & Björkman (1981) \\
\hline Sun plants & 25 & - & $2.1^{*}$ & $39.5^{\circ}$ & Björkman (1981) \\
\hline
\end{tabular}

Rico plants. In Florida Bay, Zieman et al. (1989) reported leaf production in $H$. wrightii ranging from 126 to $277 \mu \mathrm{mol} \mathrm{C} \mathrm{g}^{-1} \mathrm{dw} \mathrm{h}^{-1}$. In studies of $H$. uninervis in the Red Sea, Beer \& Waisel (1982) reported an $I_{k}$ value of $300 \mu \mathrm{mol} \mathrm{m} \mathrm{m}^{-2} \mathrm{~s}^{-1}$, $I_{c \text { (leaf) }}$ values of 20 to $40 \mu \mathrm{mol}$ $\mathrm{m}^{-2} \mathrm{~s}^{-1}$, and $P_{\max }$ values of $21 \mu \mathrm{mol} \mathrm{O} \mathrm{O}_{2} \mathrm{mg} \mathrm{chl} \mathrm{h}{ }^{-1}$. Interestingly, we found light-saturated rates of photosynthesis, expressed per unit chlorophyll content, for $H$. wrightii and other seagrasses similar to values reported for other aquatic plants and in terrestrial leaves (Table 4). However, photosynthetic production in submerged aquatic macrophytes per unit biomass or surface area is usually lower than in terrestrial plants, as noted by Nielsen \& Sand-Jensen (1989), because of the thinner leaves and thus lower chlorophyll content possessed by submerged plants. The chlorophyll content and chl $a: c h l b$ ratios presented in this paper for blade tissue of $H$. wrightii are in general agreement with results for a variety of seagrasses (Drew 1978 , Wiginton \& McMillan 1979, Dennison \& Alberte 1982, Garcia et al. 1991, Zimmerman et al. 1991).

The measurements of photosynthetic production presented here provide a more realistic estimate of the in situ physiological light requirements for Halodule wrightii. In situ measurements are valuable because they take into account problems relating to self-shading (Pérez \& Romero 1992) and natural variations in underwater irradiance. These estimates are useful in calculating net carbon balances under different light regimes and in theoretical calculations of the minimum daily quantum requirements of $H$. wrightii based on models that utilize parameters of $H_{\text {sat }}$ and $H_{\text {comp. Mean }}$ ratios of net photosynthesis to dark respiration $\left(P_{\text {net }}: R\right)$, useful indicators of plant productivity (Bowes \& Salvucci 1989), generally ranged from 2 to 4 for $H$. wrightii, slightly lower than blade $P_{\text {net }}: R$ ratios reported for Zostera marina (Zimmerman et al. 1991). However, $P_{\text {net }}: R$ values for $H$. wrightii include the respiratory demands of below-ground tissue as well as leaves. Based on our observations of the depth distribution and productivity of $H$. wrightii in Texas estuaries, the $P$ vs $I$ parameters derived from whole plant incubations are more realistic than laboratory-derived values and can be used reliably in models that address seagrass production and their minimum light requirements. However, uncertainty with respect to the carbon demands and role of below-ground tissue continue to compromise our ability to effectively manage seagrass populations that are increasingly subjected to chronic reductions in underwater light.

Acknowledgements. We thank our enthusiastic field crew, $\mathrm{S}$. Archer, B. Hardegree (who always found the site), T. Olson, and J. Tolan and our equally cheery laboratory technicians $M$. Herndon and K. Jackson for their excellent support of this research. Our gratitude and special thanks to S. Schonberg for again providing crucial computational and graphical assistance. This study benefited greatly from discussions with many colleagues, most of whom are referenced in this paper We also gratefully thank C. Onuf, J. Lawrence and 2 anonymous reviewers who provided very helpful and constructive criticisms on earlier drafts of this manuscript. The work was supported by the Texas Higher Education Coordinating 
Board, Advanced Technology Program (Grant No. 4541 and 3658-264) and by Grant No. NA89AA-D-SG139 from the National Oceanic and Atmospheric Administration to the Texas Sea Grant College Program.

\section{LITERATURE CITED}

Beer, S., Waisel, Y. (1982). Effects of light and pressure on photosynthesis in two seagrasses. Aquat. Bot. 13: 331-337

Björkman, O. (1981). Responses to different quantum flux densities. In: Lange, O. L., Nobel, P. S., Osmond, C. B., Zigler, H. (eds.) Physiological plant ecology, Vol. I Responses to the physical environment. Springer, Berlin, p. $57-108$

Bjorndal, K. A. (1980). Nutrition and grazing behavior of the green turtle Chelonia mydas. Mar. Biol. 56: 147-154

Bowes, G., Salvucci, M. E. (1989). Plasticity in the photosynthetic carbon metabolism of submersed aquatic macrophytes. Aquat. Bot. 34: 233-266

Bulthuis, D. A. (1987). Effects of temperature on photosynthesis and growth of seagrasses. Aquat. Bot. 27: $27-40$

Chalker, B. E. (1980). Modelling light saturation curves for photosynthesis: an exponential function. J theor. Biol. 84 : 205-215

Cornelius, S. E. (1977). Food and resource utilization by wintering redheads on Lower Laguna Madre. J. Wildl. Mgmt 41: $374-385$

Coutinho, R., Zingmark, R. (1987). Diurnal photosynthetic responses to light by macroalgae. J. Phycol. 23: 336-343

Czerny, A.B. (1994). Growth and photosynthetic responses of two subtropical seagrasses, Thalassia testudinum and Halodule wrightii to in situ manipulations of irradiance. M.Sc. thesis, Department of Marine Science, The University of Texas at Austin

Dawes, C. J., Tomasko, D. A. (1988). Depth distribution of Thalassia testudinum in two meadows on the west coast of Florida; a difference in effect of light availability. P.S.Z.N. I: Mar. Ecol 9: 123-130

Dennison, W. C. (1987). Effects of light on seagrass photosynthesis, growth and depth distribution. Aquat. Bot. 27: $15-26$

Dennison, W. C., Alberte, R. S. (1982). Photosynthetic responses of Zostera marina L. (Eelgrass) to in situ manipulations of light intensity. Oecologia 55: 137-144

Dennison, W C., Alberte, R. S. (1985). Role of daily light period in the depth distribution of Zostera marina leelgrass). Mar. Ecol. Prog. Ser. 25: 51-61

Drew, E. A. (1978). Factors affecting photosynthesis and its seasonal variation in the seagrasses Cymodocea nodosa (Ucria) Aschers, and Posidonia oceanica (L.) Delile in the Mediterranean. J. exp. mar. Biol. Ecol. 31: 173-194

Drew, E. A. (1979). Physiological aspects of primary production in seagrasses. Aquat. Bot. 7: 139-150

Dunton, K. H. (1990). Production ecology of Ruppia maritima L. S.I. and Halodule wrightii Aschers in two subtropical estuaries. J. exp. mar. Biol. Ecol. 143: 147-164

Dunton, K. H. (1994). Seasonal growth and biomass of the subtropical seagrass Halodule wrightii in relation to continuous measurements of underwater irradiance. Mar Biol. (in press)

Dunton, K. H., Jodwalis, C. M. (1988). Photosynthetic performance of Laminaria solidungula measured in situ in the Alaskan High Arctic. Mar. Biol. 98: 277-285

Durako, M. J. (1993). Photosynthetic utilization of $\mathrm{CO}_{\text {zlaci) }}$ and $\mathrm{HCO}_{3}{ }^{-}$in Thalassia testudinum (Hydrocharitaceae). Mar. Biol. 115: 373-380
Eleuterius, L. N. (1987). Seagrass ecology along the coasts of Alabama, Louisiana, and Mississippi. In: Durako, M. J., Phillips, R, C., Lewis, R. R. III (eds.) Proceedings of the Symposium on Subtropical-tropical Seagrasses of the Southeastern United States. Florida Marine Research Publications, St. Petersburg, p. 11-24

Fourqurean, J. W., Zieman, J. C. (1991). Photosynthesis, respiration and whole plant carbon budget of the seagrass Thalassia testudinum. Mar. Ecol. Prog. Ser. 69: 161-170

Fry, B., Parker, P. L (1979). Animal diet in Texas seagrass meadows: $\delta^{13} \mathrm{C}$ evidence for the importance of benthic plants. Estuar. coast. mar. Sci. 8: 499-509

Garcia, C. M., Perez-Llorens, J. L., Niell, F. X., Lucena, J. (1991). Pigment estimations and photosynthesis of Ruppia drepanensis Tin. ex Guss. in a hypersaline environment. Hydrobiologia 220: 147-153

Geider, R. J., Osborne, B. A. (1992). Algal photosynthesis: the measurement of algal gas exchange. Chapman and Hall, New York

Goldsborough, W. J., Kemp, W. M. (1988). Light responses of a submersed macrophyte: implications for survival in turbid tidal waters. Ecology 69: 1775-1786

Hedgpeth, J. W. (1967). Ecological aspects of the Lagund Madre, a hypersaline estuary. In: Lauff, G. H. (ed.) Estuaries. American Association for the Advancement of Science, Washington, DC, p. 408-419

Hellier, T. R. Jr (1962). Fish production and biomass studies in relation to photosynthesis in the Laguna Madre of Texas. Publs. Inst mar. Sci. Univ. Texas 8: 1-22

Jassby, A. D., Platt, T. (1976). Mathematical formulation of the relationship between photosynthesis and light for phytoplankton. Limnol. Oceanogr. 21: 540-547

Jeffrey, S. W., Humphrey, G. F. (1975). New spectrophotometric equations for determining chlorophylls $a, b, c_{1}$ and $c_{2}$ in higher plants, algae and natural phytoplankton. Biochem. Physiol. Pflanz. 167: 191-194

Jewett-Smith, J. (1991). Factors influencing the standing crop of diatom epiphytes of the seagrass Halodule wrightii Aschers. in south Texas seagrass beds. Contrib. mar. Sci. Univ. Texas 32: 27-39

Libes, M. (1986). Productivity-irradiance relationship of Posidonia oceanica and its epiphytes. Aquat. Bot. 26: 285-306

Lindeboom, H. J., Sandee, A. J. J. (1989). Production and comsumption of tropical seagrass fields in eastern Indonesia measured with bell jars and microelectrodes. Neth. J Sea Res. 23: 181-190

Markager, S., Sand-Jensen, K. (1992). Light requirements and depth zonation of manine macroalgae. Mar. Ecol. Prog Ser. 88: 83-92

Marsh, J. A., Dennison, W. C., Alberte, R. S. (1986). Effects of temperature on photosynthesis and respiration in eelgrass (Zostera marina L.). J. exp. mar. Biol. Ecol. 101: 257-267

McMahan, C. A. (1969). The food habits of ducks wintering on Laguna Madre, Texas. M.Sc. thesis, New Mexico State University, Las Cruces

McRoy, C. P., Helfferich, C. (1980). Applied aspects of seagrasses. In: Phillips, R. C., McRoy, C. P. (eds.) Handbook of seagrass biology, an ecosystem perspective. Garland STPM Press, New York, p. 297-343

McRoy, C. P., McMillan, C. (1977). Production ecology and physiology of seagrasses. In: McRoy, C. P., Helfferich, C. (eds.) Seagrass ecosystems: a scientufic perspective. Dekker, New York, p. 53-81

Merkord, G. W. (1978). The distribution and abundance of seagrasses in Laguna Madre of Texas. M.Sc. thesis, Texas A \& I University, Kingsville

Morgan, M. D., Kitting, C. L. (1984). Productivity and utiliza. 
tion of the seagrass Halodule wrightii and its attached epiphytes. Limnol Oceanogr. 29: 1066-1076

Nielsen, S. L., Sand-Jensen, K. (1989). Regulation of photosynthetic rates of submerged rooted macrophytes. Oecologia $81: 364-368$

Odum, H. T., Wilson, R. F. (1962). Further studies on reaeration and metabolism of Texas bays, 1958-1960. Publ. Inst. Mar. Sci. Univ. Texas 8: 23-55

Olesen, B., Sand-Jensen, K. (1993). Seasonal acclimatization of eelgrass Zostera marina growth to light. Mar. Ecol. Prog. Ser. 94: 91-99

Onuf, C. P. (1994). Seagrasses, dredging, and light in Laguna Madre, Texas, USA. Estuar. coast. Shelf Sci. (in press)

Parsons, T. R., Maita, Y., Lalli, C. M. (1984). A manual for chemical and biological methods for seawater analysis. Pergammon Press, New York

Pérez, M., Romero, J. (1992). Photosynthetic response to light and temperature of the seagrass Cymodocea nodosa and the prediction of its seasonality. Aquat. Bot. 43: 51-62

Porra, R. J., Thompson, W. A., Kriedemann, P. E. (1989). Determination of accurate extinction coefficients and simultaneous equations for assaying chlorophylls $a$ and $b$ extracted with four different solvents: verification of the concentration of chlorophyll standards by atomic absorption spectroscopy. Biochim. Biophys. Acta 975: 384-394

Quammen, M. L., Onuf, C. P. (1993). Laguna Madre: seagrass changes continue decades after salinity reduction. Estuaries 16: $302-310$

Ralston, M. L., Jennrich, R. I. (1978). Dud, a derivative-free algorithm for non-linear least-squares. Technometrics 20 : $7-14$

This article was presented by J. M. Lawrence (Senior Editorial Advisor), Tampa, Florida, USA
SAS Institute, Inc. (1987). SAS/STAT guide for personal computers, version 6 edn. SAS Institute, Inc., Cary, NC

Stockwell, D. A., Buskey, E. J., Whitledge, T. E. (1993). Studies on conditions conducive to the development and maintenance of a persistent 'brown tide' in Laguna Madre, Texas. In: Smayda, T J., Shimizu, Y (eds.) Toxic phytoplankton blooms in the sea. Elsevier Science Publishers, Amsterdam, p. 693-698

Strickland, J. D. H., Parsons, T. R. (1972). A practical handbook of seawater analysis. Bull. Fish. Res. Bd Can. 167 1-310

Thayer, G. W., Wolfe, D. A., Williams, R. B. (1975). The impact of man on seagrass systems. A.m. Scient. 63: 288-296

Wetzel, R. L., Penhale, P. A. (1983). Production ecology of seagrass communities in the lower Chesapeake Bay. Mar. Technol. Soc. J. 17: 22-31

Wiginton, J. R., McMillan, C. (1979). Chlorophyll composition under controlled light conditions as related to the distribution of seagrasses in Texas and the U.S. Virgin Islands. Aquat. Bot. 6 : $171-184$

Williams, S. L., McRoy, C. P. (1982). Seagrass productivity: the effect of light on carbon uptake. Aquat. Bot. 12: 321-344

Zieman, J. C., Fourqurean, J. W., Iverson, R. L. (1989). Distribution, abundance and productivity of seagrasses and macroalgae in Florida Bay. Bull. mar. Sci 44: 292-311

Zimmerman, R. C., Smith, R. D., Alberte, R. S. (1989). Thermal acclimation and whole-plant carbon balance in Zostera marina L. (eelgrass). J. exp. mar. Biol. Ecol. 130: 93-109

Zimmerman, R. C., Reguzzoni, J. L., Wyllie-Echeverria, S. Josselyn. M., Alberte, R. S. (1991). Assessment of environmental suitability for growth of Zostera marina L. (eelgrass) in San Francisco Bay. Aquat. Bot. 39: 353-366

Manuscript first received: August 13, 1993

Revised version accepted: January 25, 1994 